\title{
Under the Epidemic Situation: The Study of Bilateral Trade Zone and Agreement Between China and Korea
}

\author{
Naipeng Bu ${ }^{1,2}$, Haiyan Kong ${ }^{1,2}$, M. Saddam Hussain ${ }^{1} \&$ Sareema Fatima ${ }^{3}$ \\ ${ }^{1}$ Business School, Shandong University, Weihai, China \\ ${ }^{2}$ International Institute of Tourism Science Research, Weihai, China \\ ${ }^{3}$ Management Sciences, Government College University, Faisalabad, Pakistan \\ Correspondence: M. Saddam Hussain, Ph.D. Candidate, Business School, Shandong University, Weihai, Shandong, \\ China. E-mail: muhammad.saddam47@yahoo.com
}

Received: July 29, 2020

doi:10.5430/jms.v11n4p1
Accepted: August 29, 2020

Online Published: November 15, 2020

URL: https://doi.org/10.5430/jms.v11n4p1

\begin{abstract}
In 2019, Coronavirus outbroke, and many countries in the world were impacted by COVID-19. The COVID-19 epidemic has clouded the global economic outlook. In the current dynamic situation of the world, businesses have need to integrated internationally. Chinese and Korean government has progressively upgraded the free trade zones (FTZ) to attract greater foreign investment and tourism development. In this article, we discuss the important factors for tariff concessions in the China and Korea free trade agreement (FTA). Further, according to Korean Tourism Development Bureau (KTDB), in perspective of tourism China and Korea are more prominent in the Universal Economy. Chinese and Korean tourists are rapidly integrated in the world. Consequences created by Free Trade Zone, it is suggested that both countries should consider strategies to combat negative factors by diversifying the range of products and services and both countries can also use tourism-related professionals in areas that support FTZ's economic development.
\end{abstract}

Keywords: epidemic situation, bilateral trade zone, FTA, tourism, China, Korea

\section{Introduction}

In 2019, Coronavirus outbroke, and many countries in the world were impacted by COVID-19. Except the doctors and experts who were fighting against the virus in the front line, Chinese government calls people to stay at home to avoid infection.

The COVID-19 epidemic has clouded the global economic outlook. The International Monetary Fund (IMF) has recently reduced its forecast for global economic growth for 2020 from $3.3 \%$ to $2.9 \%$. Meanwhile, the Organization for Economic Cooperation and Development (OECD) is expected to change their forecast from $2.9 \%$ to $2.4 \%$. The epidemic has affected regional trade development in China and South Korea to varying degrees, which are reflected in the resumption of work and production, return of employees, logistics and transportation, and supply chain stability.

According to the current information available to the public, the epidemic mostly affects the personnel and material exchanges between China and South Korea. By the end of February, the passenger flights between China and South Korea were only approximately one-third of those agreed upon by the two sides. Moreover, the number of freight flights dropped by approximately $70 \%$. The epidemic has disrupted the normal operation of some enterprises because of the suspension of communication between people and the barriers against the exchange goods. Hyundai, for example, has announced that some of its factories have been shut down given the lack of supply of custom circuit boards from China. According to the survey conducted by the Korea Trade Association, the epidemic has affected approximately $77 \%$ of the local manufacturing and foreign trade enterprises with Chinese ties. The statistics from South Korea from February 1 to 20 show that the exports from South Korea to China dropped by 6.6\%, whereas exports from China to South Korea fell by $19 \%$. The possible escalation of the epidemic will affect domestic demands and cause immense pressure on the bilateral trade between China and South Korea.

In the context of trade structure, exports from China to South Korea are mainly mechanical and electrical products, chemical industry-related products, and textile raw materials and products, which accounted for $46.0 \%, 8.9 \%$, and 
7.3\%, respectively. The total exports from China to South Korea in 2019 accounted for more than 60\%. China's imports from South Korea are mainly mechanical and electrical products, chemical industry-related products, and optical and medical instruments, which accounted for $58.0 \%, 11.8 \%$, and $7.5 \%$, respectively, thus accumulating over $70 \%$ in 2019. The trade structure of China and South Korea is based on the division of labor within the industry with the electromechanical sector as the main industry. At present, the epidemic has decelerated the production activities of China and South Korea, which will interactively affect the production, operation, and bilateral trade of the abovementioned mechanical and electrical products and their related products. Such problem will gradually grow, especially the resumption of the production of computers and electronics, and will significantly affect other industrial enterprises that must import intermediate products from South Korea.

From the perspective of industrial chain cooperation, semiconductors, automobiles, electronics, and other related industry cooperation will be greatly affected as mechanical and electrical products comprise the majority of the China-South Korea trade. Taking the semiconductor industry as an example, South Korea is an important global supplier of core components, such as memory chips and CIS image sensors. They account for more than $70 \%$ of the international market for components, such as DRAM and NAND flash memories, among which Samsung and Hynix, which have been affected by the epidemic, are the major global suppliers. In the semiconductor industry chain, China, Japan, and South Korea have maintained a relatively balanced relationship. Japan produces upstream materials, South Korea produces midstream chips, and China produces downstream products. The predicted spread of the epidemic in South Korea will lead to the increase of the cost of China's system and the delay of product delivery. Such factors will affect the resumption of the production of Chinese enterprises and, especially, the development of the semiconductor industry in China. This circumstance will negatively affect the global supply chain. Automobile, consumer electronics, and other industries are basically the same. As industries with high degree of internationalization, long industrial chain, and wide global distribution, they are more vulnerable to the epidemic. The possible interruption of the production and operation of South Korea due to the epidemic will significantly impact the development of relevant industries in China and bilateral-even multilateral-economic and trade cooperation between China and South Korea.

But systemic empirical research has not been completely applied to examine or find the factors that the interplay between China-Korea bilateral trade.

This study aims to explore the factors in FTA in the current literature by important research questions.

1). Which factors will promote the trade development between China and Korea in Free Trade Agreement?

2). What will be impact on tourism for both countries?

\section{Literature Review}

Businesses need to be integrated internationally in the current dynamic situation of the world. This study aims to explore the bilateral trade between the two economies of China and Korea under the global free trade zone (FTZ) agreement scheme. On June 1, 2015, China and South Korea signed a free trade agreement (FTA) and subsequently pursued trading on December 20, 2015. According to the data from the Korea International Trade Association, China accounts for $24.8 \%$ of South Korea's exports in 2018. China, Japan, and South Korea have jointly expanded their economic power to become the world's third largest economy, following the European Free Trade Association and the member countries engaged in North American Free Trade Agreement. However, due to the lack of institutional and economic integration of China, Japan, and South Korea, the other two countries of Northeast Asia have since lagged behind in terms of development (Li \& Whalley, 2017). In the face of a rapidly integrated universal economy, nations and territories have further recognized the potential of foreign investments to bolster the development of domestic technology, employment, and trade (Borensztein et al., 1998).

China and South Korea have been important trade partners since the two countries established their economic relations in 1992. Both countries have since fostered close economic relations. The China-South Korea FTA is regarded one of the leading reasons of the economic cooperation between the two countries. The agreement is expected to bring great economic benefits, and it has a political significance for both countries, ensuring unity in East Asia. China became South Korea's largest trade partner in the past decade. South Korea expects that a FTA with China would bring considerable benefits, comparable to the profits it has gained through FTAs with other partners. Similarly, China views the FTA with South Korea as a major trade agreement, particularly as a policy to help develop and adapt to various East Asia and Pacific nations, which are influenced by United States and Japan.

Poor trade and low liberal economic systems prevail around the world. Instituting FTZs is a popular approach of piloting economic reforms, such as by offering a combination of major customs procedures, tax and tariff incentives, 
and reduced regulations. According to the state media Xinhua (n.d.), trade pacts are expected to eliminate $90 \%$ of import tariffs across 17 areas in the next two decades. Analysts expect the FTA to have taken effect as early as mid-2015. A universal economy has been characterized in the Asia Pacific. In this era, China is regarded one of the most imminent economies to date, with its reform process integrating new kinds of FTZs since 2013. Even international trade and tourism development have been integrated and is now widely accepted (Gray, 1970; Kulendran \& Wilson, 2000; Turner \& Witt, 2001).

Tiezzi (2015), reports that China and South Korea refer to certain existing FTAs, in which the agreement part is emphasized. China is currently the largest trading partner of South Korea, and Seoul hopes the agreement would deliver the same distinctive benefits as those in other international trade relations. Meanwhile, the FTA with South Korea is China's largest agreement in terms of volume of trade. Chinese investigators believe that the new FTA with South Korea "represents the highest levels of freedom of trade and open market," and it is much higher than any other FTAs that China has realized.

Garcia-Herrero et al. $(2013,2015)$ reported that the export-led model began three decades ago, and China has since become one of the world's industry players for formulated goods. China is the hub of goods production in East Asia and is a producer of different parts and tools of manufactured goods. The three trade hubs in the world are East Asia, North America, and Europe (Figure A). Each center includes large-scale trading within the region and business operations with the rest of the world. Strong trade stimulated North America and European Union's free trade. However, territorial integration currently does not exist in East Asia. Luckily, FTA schemes involving the Association of Southeast Asian Nations (ASEAN) and countries such as China, Korea, Japan, Australia, New Zealand, and India have considered entering into Regional Comprehensive Economic Partnerships (RCEP) (Li \& Moon, 2018), as shown in Figure B. The talks with ASEAN were initiated in November 2012, and 20 talks have been concluded as of December 2017.

The situation at the regional level can help highlight the establishment of China's FTZs and provide an insight into its prospective effects on tourism in Korea and China. In this study, we offer a timely reflection for Korea tourism policy makers and business experts, as well for each Asian destination manager. We also examine the elements of tariff concession in Korea in relation to FTAs, as not all tariffs on imports from China will be eliminated immediately. For instance, according to the tax analysis related to China and Korea's FTA beginning 2015, China can eliminate tax rates on $91 \%$ of South Korea's imports (accounting for $85 \%$ of the total imports from South Korea) in the next 20 years (Hyejoon, 2017). In the textile industry, clothing, functional clothing, and children's clothing - examples of Korea's sensitive goods, to include cotton fabrics and cotton threads - will maintain or reduce tax rates. The same approach is applied to electronic equipment, washing machines, refrigerators, medical equipment, rice cookers, and appliances. Meanwhile, South Korea will also eliminate tax rates on $92 \%$ of China's imports (accounting for $91 \%$ of the total imports from China) over the next 20 years, in which major products include motors and transformers from the electronic technology industry and handbags and golf clubs as household items (Hyejoon, 2017).

We expect the China-Korea FTA to first bring economic and geopolitical benefits, which will contribute to the sustainable growth of the Korean economy. According to the Korean Economic Research Center, the FTA between South Korea and China is expected to boost South Korea's real GDP by approximately $0.95 \%-1.25 \%$ in five years and $2.28 \%-3.04 \%$ in ten years. In particular, South Korea can use the China-Korea FTA to boost the pace of entry into China's domestic market, which was considered the most promising market after the economic crisis in 2008. According to the five-year economic development plan released in 2010, China has to change its approach to its goals and is currently turning into domestic demand instead of exporting (Choi, 2012). 


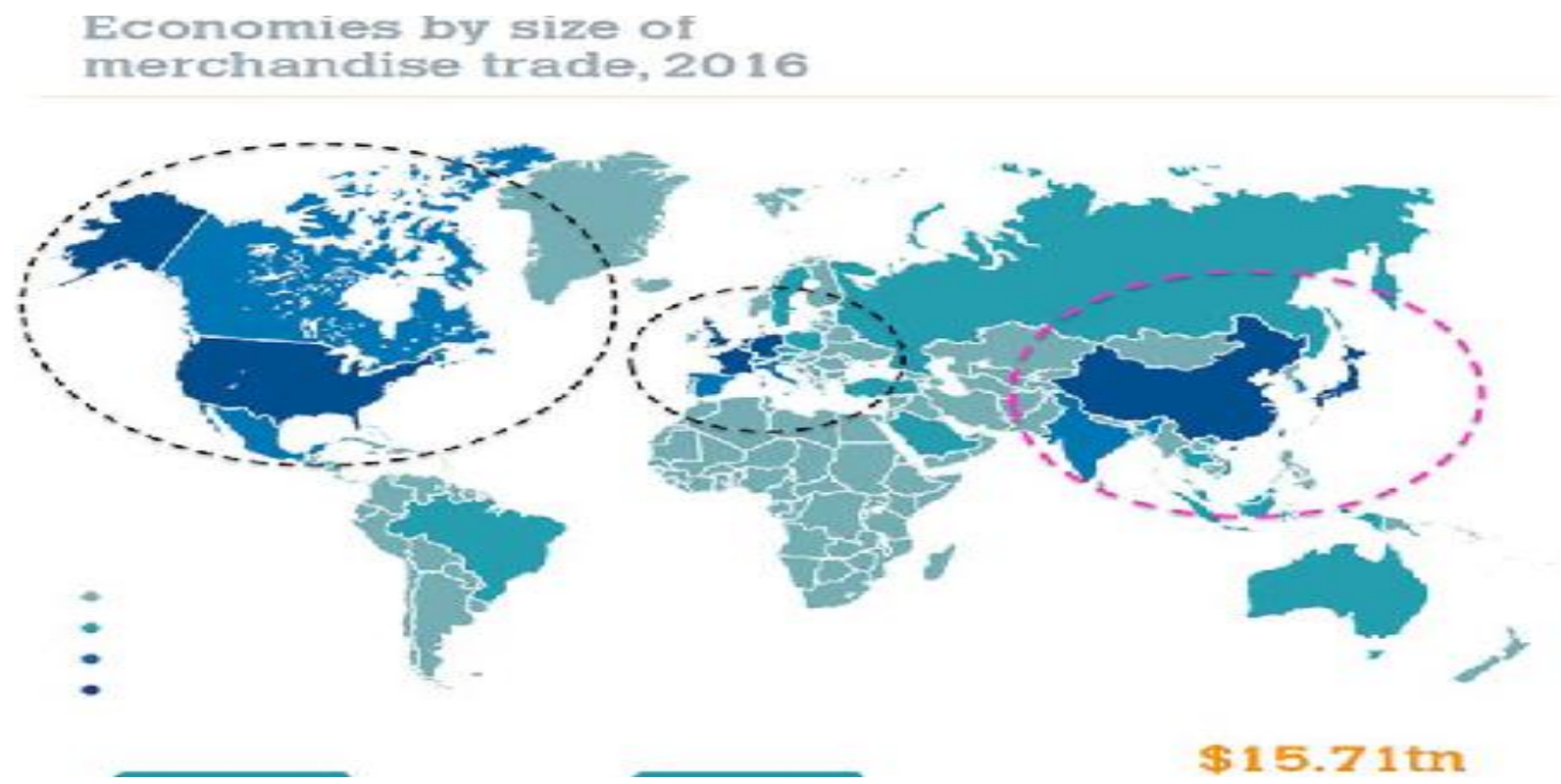

Figure 1

Source: WTO Trade Report 2017

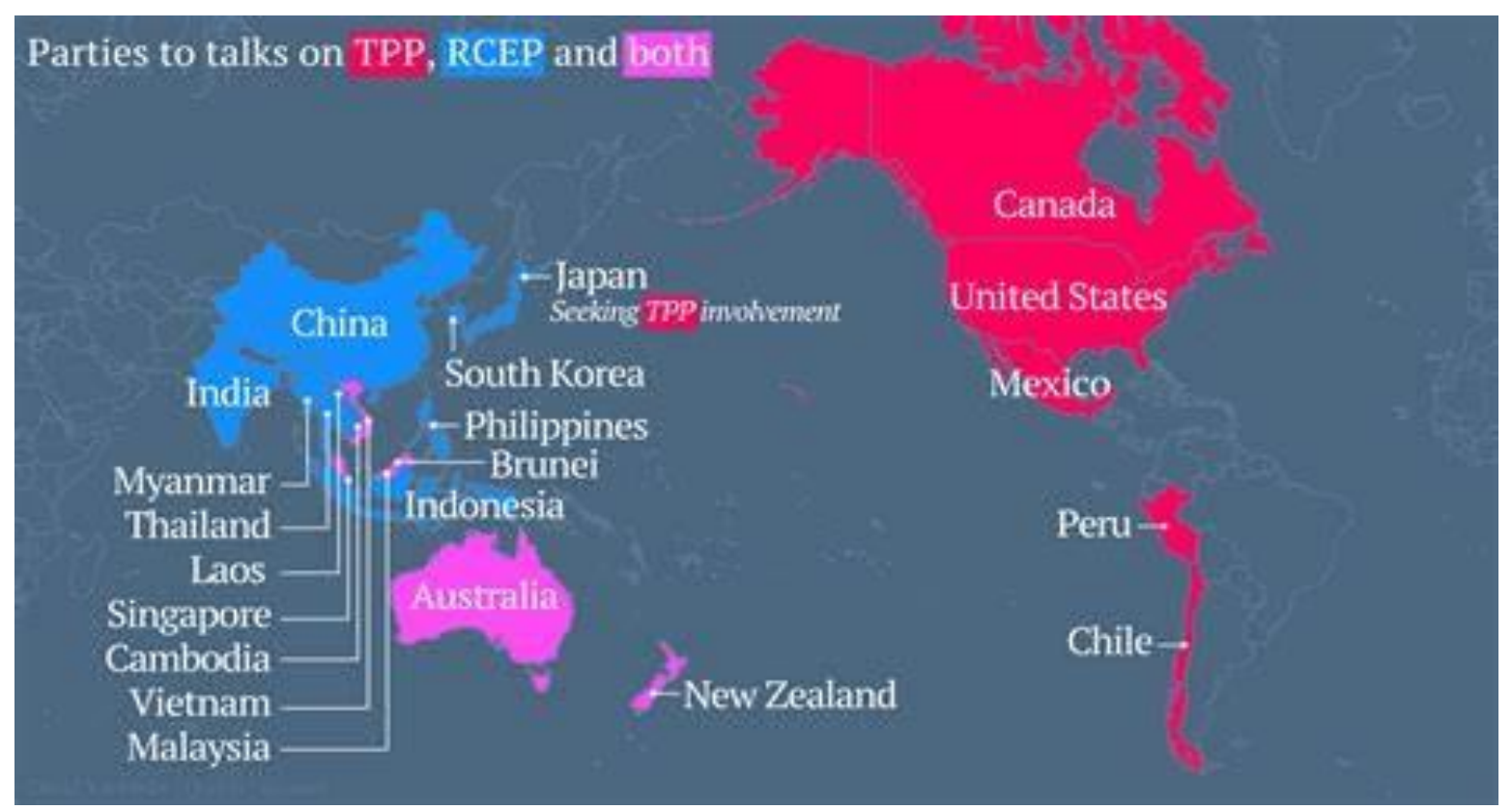

Figure 2. Negotiation among countries under RCEP

The schedule, also called the staging category, to cancel customs duties varies by product. Some products have faster tariff implementation than the others. For instance, the most favored nation's (MFN) tariff for some synthetic rubbers (e.g., butadiene, styrene, and acrylonitrile-butadiene) is $8 \%$. These tariffs will be eliminated immediately on the date of entry to enforce the FTA. At the same time, $13 \%$ tariffs are expected to be phased out in 10-20 years (Hyejoon, 2017). Some clothing types, such as sweaters and T-shirts, are also expected to be eliminated. However, other products, such as some ball bearing products and agricultural products (barley, potatoes, pork, apples, and garlic), are completely exempt from tariff reductions and free of the obligation to lower the tariffs. In the same tax analysis 
mentioned above, in China and Korea's FTA starting 2015, if the goods fall under the schedule of tariff concessions, the mere shipments of goods from Korea to China or vice versa is not sufficient to qualify for a preferential duty rate. Two requirements need to be met to enjoy the FTA benefits: the goods are classified as "originating goods," and they will need to be transported directly.

Similar to the previous studies, we found that the decisive factors affecting tariff preference include the share of Chinese imports from South Korea, the competitiveness of Korean products versus Chinese products, the current MFN tariffs, and the products of sensitive sectors in South Korea, whether the product is agricultural or not (Hyejoon, 2017). In addition, South Korea and China maintain tariffs on a large number of manufactured products, such as automotive, electronics, steel, and petrochemicals. China and South Korea have also agreed on cars and car parts to be withdrawn from changes in fixed or long-term payments. The opt-out category for the most sensitive products in China maintains $25 \%$ of the import price, and the taxes on Korean cars and accessories, such as mufflers, range from $10 \%$ to $45 \%$ (MOTIE, 2015b). Korean companies, such as Hyundai and Kia, are already manufacturing in China. However, prices hamper the company's ability to replicate regional production. Furthermore, the automobile workers of Korea will not likely benefit from the scheme. The FTA does not include certain electronic products. For instance, China does not import lithium batteries, TV panels, and OLED panels for television, and the 5\% rates are offered for LCD monitors only. For steel products, China has agreed on zero tariffs for the importation of basic goods, although the maximum protection for value-added products and their relatively high prices are now slowly opening. The tax clearance scheme is also somewhat complex. A good example is China's 7\% tariff on steel, but the products become tax-free when they involve building components, such as basic steel materials (Jeffrey J. Schott, 2015). This scheme is expected to be completed in 10 years, in which the value-added products include electrical or galvanized steel. In general, an $8 \%$ charge and is the exemption rate. South Korea maintains high protection for its agricultural products. Taxes will be raised to $64 \%$ for agricultural products in 20 years; within the first 10 years, $36.6 \%$ of the taxes will be removed from the products (Xu, 2014).

According to Pak (1997), China's first FTZ was established in 1980, with focus on exports and manufacturing. The bilateral trade agreement between China and Korea came into being in December 1, 2015, although not all Chinese importation tariffs were eliminated immediately. Some product costs were abolished rapidly than others. This study is intended to explore the trade relation between China and Korea under the "one belt, one road" scheme embodied by FTZs. Furthermore, this study investigates the degree of impact of FTAs on both countries' trade and tourism.

Song Qinghui, a famous economist, shared to International Online reporters that certain indications in the SinoKorean free trade area can be regarded a high-level FTZ. The first breakthrough provides examples of the "free trade area" along the "one belt, one road," and it is also an important breakthrough in promoting the FTZ strategy at the national level. The success of the China-Korea FTA will certainly inspire China-Russia, China-Japan, and ChinaKorea FTAs. A further expansion and development of FTAs in Northeast Asia may mean a China-ASEAN FTA, further setting China's growth the Northeast Asia FTAs. China and South Korea, after signing the FTA, have both been offered a great potential to open up.

According to researcher Cui, "In China and South Korea, imports of machinery and equipment grew the most, reaching $\$ 1,552.43$ million, up by $\$ 586.68$ million, and up by $5.41 \%$ and $8.37 \%$. The liberalization ratio of goods traded between the two countries has exceeds $90 \%$ of the tariff items and $85 \%$ of the trade (Cui et al. 2019). The agreement covers a wide range of areas, including 17 areas of goods, services, investment and rules, in addition to the standard content of conventional FTAs, and even launches negotiations on '21st century economic and trade issues'." Relevant statistics also show that China's foreign direct investment (FDI, based on declared amount) in Korea in 2016 accounted for $9.6 \%$ of the total FDI in the same year (\$2049.17 billion), reaching 1940 times of that in 1992. Over the same period, South Korea's FDI in China has increased from $\$ 223.28$ billion to $\$ 4,017.3$ billion, an increase of nearly 18 times from the base figure, enabling China to become the largest trading country of South Korea (Cui et al. 2019).

In the Sino-Korean FTA, the two countries have agreed to open more than $90 \%$ of the product tax items and $85 \%$ of the trade volume. In particular, $71 \%$ and $79 \%$ of the products, $66 \%$ and $77 \%$ of the trade volume, $91 \%$ and $92 \%$ of the products, and $85 \%$ and $91 \%$ of the trade volume of China and Korea will be phased out in 10 years (Cui et al. 2019). In terms of industrial products, South Korea has a relatively high level of openness. A high rate of $97.6 \%$ of Korean industrial products should have abolished tariffs in 20 years, a rate higher than $90.3 \%$ of China's level of openness (Cui et al. 2019). In terms of agricultural products and aquatic products, China has a relatively high level of openness. Approximately $91 \%$ of China's agricultural products and $99 \%$ of its aquatic products have gradually eliminated tariffs in 20 years, while the corresponding level of openness in Korea is only $64 \%$ and $86.2 \%$ (Cui et al. 
2019).

According to Kim Hyeon Kuk, "Compared with the previous FTAs, South Korea has shown more protection mechanisms, releasing $30 \%$ of the material that is $60 \%$ of imports (Kim, 2016). South Korea slows down the market opening by excluding major items, such as rice and hot food (pepper, garlic, beef and pork)." Meanwhile, China has eliminated 93\% of its agricultural tax. The so-called 102 Critical Issues, including sugar, flour, and tobacco, have been discontinued. In addition, instant noodles should be eliminated from the payment to be made in the 20 -year agreement. Pork and beef are South Korea's most serious issue in terms of food and have been unrestricted. Therefore, the value of production and trade has not changed drastically. However, in some areas of the meat industry, exports will grow to almost zero (i.e., 5.71\%) (Kim, 2016). In addition, production, imports, and prices are projected to increase slightly. As for fruits and vegetables, a trading site has shown the clear benefits of Chinese products; they have been exempted from tax liability. Therefore, production, consumption, and price levels will not be affected significantly.

\section{Findings and Discussions}

Overall, the competition is limited in other parts of the sale scheme for products, but the competition has become extremely high. The China-South Korea FTA will have a positive impact on both countries. However, holistic approaches will only likely benefit the large industries. For example, in agriculture, meat products (other than fish and beef products) will have good market opportunities. The Chinese government needs to take steps to increase the exportation of meat. At the same time, steps should be taken, and compensation should be rendered, for negatively affected industries. We have yet to know if impact to the sugar industry will be good. Although South Korea is not a major producer of sugar, the food industry has been a prime focus and thus should be improved. China likely needs to develop mechanisms to protect vulnerable sectors. Overall, the China-Korea FTZ will lead China to become more developed and efficient in industrial building. The FTZ has a positive impact on the Chinese economy.

Table 1. Import and export trade statistics between China and Korea (1992-2015)

\begin{tabular}{lllll}
\hline Year & Total & Export & Import & Export-Import \\
\hline 1992 & 50.3 & 24.1 & 26.2 & -2.1 \\
\hline 1993 & 82.2 & 28.6 & 53.6 & -25 \\
\hline 1994 & 117.2 & 44.0 & 73.2 & -29.2 \\
\hline 1995 & 169.8 & 66.9 & 102.9 & -36 \\
\hline 1996 & 199.8 & 75.0 & 124.8 & -49.8 \\
\hline 1997 & 240.6 & 91.3 & 149.3 & -58 \\
\hline 1998 & 212.6 & 62.5 & 150.1 & -87.6 \\
\hline 1999 & 250.4 & 78.1 & 172.3 & -94.2 \\
\hline 2000 & 345 & 112.9 & 232.1 & -119.2 \\
\hline 2001 & 359.1 & 125.2 & 233.9 & -108.7 \\
\hline 2002 & 440.71 & 154.97 & 285.74 & -130.77 \\
\hline 2003 & 632.3 & 201.0 & 431.3 & -230.3 \\
\hline 2004 & 900.68 & 278.18 & 622.50 & -344.32 \\
\hline 2005 & 1119.31 & 351.09 & 768.22 & -417.13 \\
\hline 2006 & 1343.05 & 445.26 & 897.79 & -452.53 \\
\hline 2007 & 1598.98 & 561.41 & 1037.57 & -476.16 \\
\hline 2008 & 1861.13 & 739.51 & 1121.62 & -382.11 \\
\hline 2009 & 1409.5 & 542.5 & 867.0 & -324.5 \\
\hline 2010 & 2071.7 & 687.71 & 1383.99 & -696.28 \\
\hline 2011 & 2456.33 & 829.24 & 1627.09 & -797.86 \\
\hline & & & &
\end{tabular}




\begin{tabular}{lllll}
\hline 2012 & 2563.29 & 876.81 & 1686.48 & -809.66 \\
\hline 2013 & 2742.49 & 911.76 & 1830.73 & -918.97 \\
\hline 2014 & 2905.64 & 1003.56 & 1902.08 & -898.53 \\
\hline 2015 & 2273.77 & 902.37 & 1371.4 & -469.03 \\
\hline 2016 & 2113.9 & 869.6 & 1244.3 & -374.7 \\
\hline 2018 & 2399.8 & 978.6 & 1421.2 & -442.6 \\
\hline
\end{tabular}

Tourism is likely to be the Korean services sector to benefit greatly from the FTA, as China has allowed Korean companies to open local offices in China and remove restrictions on the tourism industry. However, the FTA has failed to renew the reach of China's service industries within the expected range. China and South Korea have a long history, and their tourism markets have developed rapidly in recent years. From 1990 to 2013, the number of Korean tourists entering China increased from 3.969 million to 10.2 million, surpassing Japan as China's largest international tourist market (Liu, 2018). The number of tourists increased from 205,000 to 3,923,000, an increase of $43.6 \%$ in 2013 over the previous year (Piao \& Meng, 2016). For the first time, China has surpassed Japan to become the largest international tourist market in South Korea. Tourism cooperation between China and South Korea has become increasingly close. With the development of the global economy, the service trade between China and Korea is becoming more prominent in tourism, finance, and other aspects.

According to statistics, the number of South Korean tourists visiting China increased by more than three times in 2014 than in 2000. Relevant statistics also show that Korea has become the main source of foreign inbound tourism as of 2016. The number of Chinese tourists visiting Korea has also increased year by year. The establishment of the China-Korea FTA has dramatically improved both in terms of transportation and tourism investment, benefitting the tourists of the two countries. According to the data released by the Korea Tourism Development Bureau, Korea received approximately 153.47 million foreign tourists in 2018. Among them, the number of tourists in mainland China has reached 4789,000 , accounting for $31.2 \%$ of the total number of foreign tourists. The tourists in mainland China have increased by $14.9 \%$ year-on-year (Echo, 2017).

A reporter, Echo Huang, in her/his journal in 2017 said that "No other country can feel China's angry outbursts as economic as South Korea." The South Korea National Budget Office estimates that China's decision not to stop the South Korean tourism industry outweighed Seoul's decision to install a US anti-waste plan, which costs the economy approximately $\$ 7.5$ trillion ( $\$ 6.8$ billion). China has been South Korea's biggest tourist source since 2013, and China accounts for nearly half of the 17 million people who visited Korea in 2016. However, a decline of tourists in Seoul and Beijing has also been recorded. The number of Chinese tourists visiting South Korea decreased in MarchOctober in 2017. The same scenario has been observed for South Korean tourists, dropping more than 60\% in 2017 compared with the same period the previous year (Echo, 2017).

After Seoul refused to block the implementation of antiretroviral treatment programs, the relations between the two countries plummeted beginning March 2017. The controversial plan is called Terminal High Altitude Area Defense (THAAD), which Beijing believes threatens national security. As a result, the China National Tourism Administration has informed tourists to halt the sale of travel packages to South Korea. By December 20, 2017, the South Korean media reported that China further enhanced on blockade of South Korean party travel. The news led Korean companies (e.g., cosmetics companies and hotels) and tourists themselves to rely heavily on international tourism industry.

The Korea Federation of Industries (FKI) announced on November 11, 2017 that the number of Chinese tourists visiting Korea in 2016 reached 8,068 million because of a ban on South Korea's group tour by the China National Tourism Administration, which dropped to 4,790,000 the previous year. Korea began its operation in August 2016. During the same period, the number of Chinese tourists visiting Japan increased from 6,374,000 to 8.38 million. In addition to China's answer to THAAD, the investment between South Korea and China increased from $\$ 6.08$ billion in 2016 to $\$ 8.4$ billion in 2018. In particular, South Korea's investment in China increased by $40.3 \%$ to $\$ 5.66$ billion, while China's investment in South Korea grew by $33.7 \%$ to $\$ 2.74$ billion. During this time, South Korea's investment in China increased from $8.67 \%$ to $9.57 \%$ (Jung, 2019).

According to the Korean Federation of Industries (KFI), China remains South Korea's most important trade, 
investment, and tourism partner, even if Korean companies have increased trade with Vietnam and India and invested in these two countries since their retaliation. FKI advises for the "Korean government to end talks of trade and investment on FTA with China, such as arranging President Xi Jinping's government visit to South Korea without delay to make relations with China possible" (Jung, 2019).

\section{Conclusions}

From the perspective of consequences and antecedents, on the basis of previous literature, not all products are treated equally in the FTA consultations on tariff preferences. In this literature, we examine the qualitative research and identify the key factors to determine the staging classification of tariff preferences in Korea and China's FTA and the rapid development of tourism cooperation between the two countries. The key results can be summarized as follow. First, similar to the previous empirical studies, we find that the decisive factors of tariff preferences in FTAs include the share of Chinese imports from South Korea, the competitiveness of Korean products versus Chinese products, the current MFN tariffs, and the products of sensitive sectors in South Korea, whether these products agricultural or not.

Second, the most influential determinants of tariff preferences in FTAs are MFN tax rates and product classification (whether the product is agricultural or not). The impact on industries is heterogeneous. The impact of China's share of imports is more apparent for agricultural products than manufactured goods. Meanwhile, MFN tariffs are less obvious to them. These determinants show that plenty of agricultural products of South Korean are strictly protected by FTA, although the rates of MFN are relatively low.

Third, according to the international tourist market, the tourism cooperation between China and South Korea has rapidly increased. From the tourism perspective, China and Korea have become increasingly prominent in the global economy. Chinese and Korean tourists are rapidly increasing year by year, as proven by the Korean TDB.

Finally, for the consequences created by FTZ, we suggest that China and Korea to consider strategies to combat negative factors by diversifying the range of products/services. Service processes should be improved, and the forecasting of resource creation from current assets should be prioritized as intangible assets in the tourism market. Such initiatives and creativity can help to diversify the over-reliance on established tourism products. Furthermore, both countries can also use tourism-related professionals in areas that support an FTZ's economic development. Services may include exhibition management, travel agency services, traffic management, development of medical professionals, and improving service management standards.

\section{References}

Borensztein, E., De Gregorio, J., \& Lee, J. W. (1998). How does foreign direct investment affect economic growth?. Journal of International Economics, 45(1), 115-135.

Choi, N. (2012). Impacts and main issues of the Korea-China FTA. Retrieved from http://keia.org/category/authors/choi-nakgyoon

Cui, L. B., Song, M. L., \& Zhu, L. (2019). Economic evaluation of the trilateral FTA among China, Japan, and South Korea with big data analytics. Computers \& Industrial Engineering, 128, 1040-1051.

Echo, H. China inflicted a world of pain on South Korea in 2017. Retrieved from https://qz.com/1149663/china-south-korea-relations-in-2017-thaad-backlash-and-the-effect-on-tourism

Garcia-Herrero, A., Fung, K. C., \& Nigrinis, M. O. (2013). Latin American commodity export concentration: is there a China effect?. BBVA Working Paper 2013, Hong Kong.

Garcia-Herrero, A., Fung, K. C., \& Seade, J. (2015). Beyond minerals: China-Latin American trans-pacific supply chain. BOFIT Policy Brief, No. 5, Bank of Finland, Helsinki.

Gray, H. (1970). International Travel-International Trade. Lexington: Heath Lexington.

Hyejoon, I. M. (2017). Not all goods are created equal: Tariff concessions in the Korea-China free trade agreement. The Singapore Economic Review, 63(1), 1-15.

Jung, S-Y. (2019). Number of Chinese Tourists Visiting South Korea Drops after China's Travel Ban. Retrieved from http://www.businesskorea.co.kr/news/articleView.html?idxno=37900

Kim, H. K. (2016). Impact of the Sino-Korea free trade agreement on China's agricultural industry. Journal of Economics and Sustainable Development. Retrieved from https://pdfs.semanticscholar.org/ea2a/152594377c6bdd212abe1add86d245d01c63.pdf

Kulendran, N., \& Wilson, K. (2000). Is there a relationship between international trade and international travel?. 
Applied Economics, 32(8), 1001-1009.

Li, C., \& Whalley, J. (2017). How close is Asia already to being a trade bloc?. Journal of Comparative Economics, 45(4), 847-864.

Li, Q., \& Moon, H. C. (2018). The trade and income effects of RCEP: implications for China and Korea. Journal of Korea Trade, 223, 306-318.

Ministry of Trade, Industry, and Energy (MOTIE). (2015a). Free Trade Agreement between the Government of the Republic of Korea and the Government of the People's Republic of China. Retrieved from http://www.fta.go.kr/cn/doc/1/

Pak, C. D. (1997). The special economic zones of China and their impact on its economic development. USA: Greenwood.

Piao, Y. J., \& Meng, X. (2016). Construction of China-South Korea Free Trade Zone from the perspective of "21st century maritime silk road". Oriental Forum, 6, 48-54.

Turner, L., \& Witt, S. (2001). Forecasting tourism using univariate and multivariate structural time series models. Tourism Economics, 7(2), 135-147.

Xinhua. S. Korea, China agree to implement FTA. Retrieved from http://www.fta.go.kr/cn/

$\mathrm{Xu}, \mathrm{X}$. (2014). A comparative study of tourism development between China and South Korea. Leshan Teachers College, 29(6), 52-57.

\section{Copyrights}

Copyright for this article is retained by the author(s), with first publication rights granted to the journal.

This is an open-access article distributed under the terms and conditions of the Creative Commons Attribution license (http://creativecommons.org/licenses/by/4.0/). 